\title{
Applications of actions for environmentally sensitive areas: Examples in Scotland
}

\author{
Robert Crabtree, John Milne* \\ Macaulay Land Use Research Institute, Craigiebuckler, Aberdeen, AB 15 8QH, UK
}

(Received 29 May 1998; accepted 6 July 1998)

\begin{abstract}
An Environmentally Sensitive Areas Scheme has been implemented in 10 designated areas of Scotland, covering $19 \%$ of Scotland's agricultural land. A Scheme has operated since 1987 and there are currently 1560 participants. The uptake of eligible units ranges from 17-59\% between areas. Objectives include protecting the nature conservation value of grazed upland vegetation, species-rich grassland and wetlands and farm woodland, repairing traditional walls and hedges and protecting historic features. Monitoring has shown that the nature conservation value has been maintained but that only limited enhancement has taken place to date. To assess the value that the general public in Scotland place on the Scheme, two contingent valuation studies have been undertaken to assess the public's willingness to pay for the potential environmental benefits. Both studies have shown that the public value the Scheme highly. Other outcomes of the Scheme have been increases in net farm income, increased rural employment, extensification of sheep and cattle production and a greater awareness of environmental issues by farmers. (C) Elsevier / Inra
\end{abstract}

environment / contingent valuation / habitats / monitoring / rural economy

Résumé - Applications de mesures agri-environmentales : exemples en Écosse. Un plan de mesures agri-environnementales a été mis en place dans dix régions d'Écosse, représentant $19 \%$ de la surface agricole totale. Le projet a débuté en 1987 et compte actuellement 1560 participants. La proportion d'exploitations satisfaisant les conditions varie de 17 à $59 \%$ selon les zones. Les objectifs du dispositif visent i) à protéger et préserver la végétation pâturée des montagnes, la prairie et les zones marécageuses riches en espèces végétales, et les zones boisées des fermes, ii) à réparer et entretenir les murs traditionnels et les haies et iii) à protéger les sites historiques. Le suivi des mesures a montré que l'environnement a été préservé mais que sa mise en valeur a été jusqu'ici limitée. Deux études d'évaluation contingente ont montré le très grand intérêt du public écossais pour ce projet. Les conséquences du dispositif pour le secteur rural ont été des augmentations du revenu net agricole et de l'emploi rural, une extensification de la production ovine et bovine, et une prise de conscience plus importante des enjeux environnementaux par les exploitants. (C) Elsevier / Inra environnement / évaluation contingente / habitat / enregistrement / économie rurale

\footnotetext{
* Correspondence and reprints

Tel.: (44) 01224318611 ; fax: (44) 0122431 15 56; e-mail: j.milne@mluri.sari.ac.uk
} 


\section{INTRODUCTION}

As part of the UK Government's response to EC regulation, EEC 2078/92, an Environmentally Sensitive Areas scheme has been implemented in 10 areas of Scotland, covering 19\% of Scotland's area (see figure I). The areas selected by the Scottish Office of the UK Government were judged to be of particular conservation interest, with a close relationship between agricultural practices and the environment. Farmers joining the voluntary scheme are eligible to receive both annual area-based payments for adopting land management practices and one-off payments for capital works, like repairing walls and for fencing, in exchange for agreeing to protect and enhance the nature conservation and landscape value of the farm through implementing a conservation plan with specified management prescriptions. There are a num-

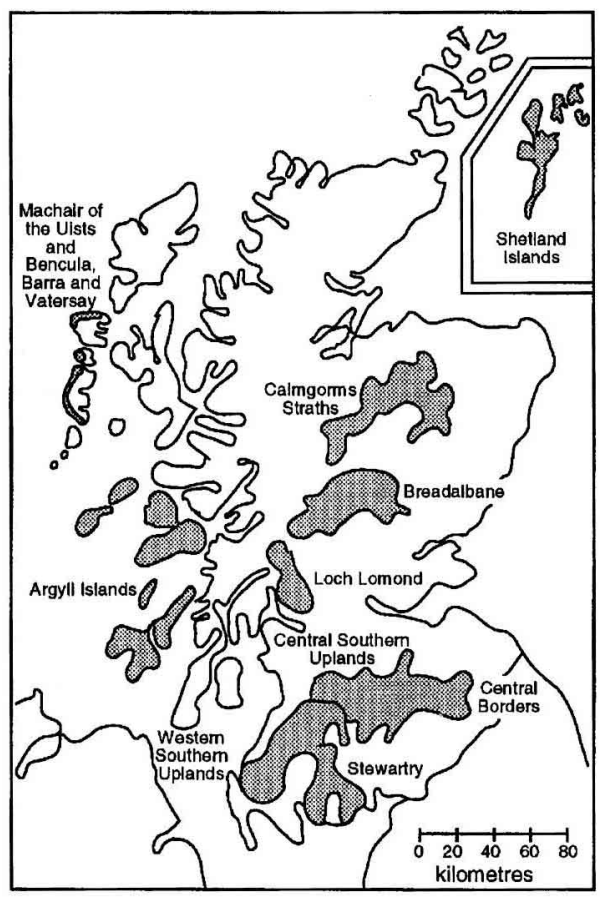

Figure 1. Areas included in Environmentally Sensitive Areas of Scotland Scheme (shaded). ber of tiers of payment of increasing complexity within the scheme with higher tiers providing for more specific environmental benefits. The scheme has been in operation since 1987 with five areas and since 1992 with the other five areas. There are currently 1560 participants in the scheme [10]. Table I shows uptake by farmers, expressed as a proportion of farmers entering the scheme, which averages $31 \%$ and ranges from 17 to $59 \%$ between areas. Of the total eligible area the uptake is $45.2 \%$ also with a wide range in uptake between areas of 15 to $72 \%$. The higher uptake on an area than a farmer basis reflects the greater uptake by larger farmers.

\section{OBJECTIVES}

The objectives differ slightly between areas but the principal objectives, which are common to most areas, are as follows: 1) protect conservation value of upland natural vegetation; 2) protect, enhance and extend herb-rich grassland and wetlands; 3 ) encourage natural regeneration of farm woodland; 4) rectify neglect of traditional farm walls and hedges; and 5) protect features of historical or archaeological interest and allow for their management.

The areas of upland natural vegetation, herb-rich grasslands and wetlands, and regenerating woodland in the Environmental Areas Scheme in Scotland in 1997 were 227445,9984 and 4336 hectares respectively. A total of $2329 \mathrm{~km}$ of farm walls and hedges had been repaired and 4749 historic sites were within the Scheme [10].

Since 1987 environmental monitoring of the original five schemes has been put in place, for example to assess the extent to which areas of heather, herb-rich grassland or woodland regeneration have increased or whether the 'quality' of these areas has continued to decline. However, the short time scale of 5 to 10 years, and the long timescale over which changes in vegetation dynamics occur, makes it difficult to draw 
Table I. Uptake of Environmental Sensitive Areas Scheme in Scotland in 1997 (derived from Scottish Office data [10]).

\begin{tabular}{lccc}
\hline & Number or area (ha) & Mean uptake (\%) & Range in uptake between areas (\%) \\
\hline Eligible units & 4756 & 31.0 & $17-59$ \\
Eligible area & 1088000 & 45.2 & $15-72$ \\
\hline
\end{tabular}

conclusions. Moreover, it is difficult to measure small changes in vegetation area and quality without a very large monitoring effort. The general nature of some of the environmental targets also makes it difficult to assess the success of the Environmental Sensitive Areas Scheme from a nature conservation perspective.

Table II shows the results of three environmental monitoring studies on different aspects of the Scheme, pertaining to nature conservation objectives. These studies compared the impact on vegetation communities within farms which joined the Environmental Sensitive Areas Scheme with similar farms which did not join the Scheme within the same geographical area. From these studies it can be concluded that, although enhancement has not been demonstrated, there has been a maintenance (and hence no decline) of the habitats in their current state. What is not in doubt is the length of walls repaired, $2329 \mathrm{~km}$, and the number of features of historic/archaeological interest maintained (4 749).

\section{ECONOMIC EVALUATION OF THE BENEFITS OF ENVIRONMENTALLY SENSITIVE AREA SCHEMES}

Since the environmental benefits of Environmentally Sensitive Areas are not priced through market processes, methods have been developed for attaching a value to the benefits received from environmental goods. In two Scottish studies which have been conducted the contingent valuation method has been used [4]. The studies used a combination of postal questionnaire (400 questionnaires sent out per Environmental Sensitive Area Scheme) and interviews (100 interviews per Environmental Sensitive Area Scheme). This method establishes a hypothetical market for the goods in question and seeks to identify the public's willingness to pay to secure the environmental benefits or prevent environmental losses. The method involves asking representative samples of the public, which can be residents of an area, visitors or the general pub-

Table II. Conclusions of environmental monitoring of Environmental Sensitive Areas Schemes in Scotland (1988-1993).

\begin{tabular}{|c|c|c|c|}
\hline Area & Variables measured & Outcome & Reference \\
\hline Breadalbane & Heather utilisation & Maintained and greater outside area & {$[5]$} \\
\hline & & & \\
\hline \multirow[t]{2}{*}{ Loch Lomond } & Heather utilisation & Maintained but greater outside area & [5] \\
\hline & Woodland regeneration & No increase in sapling height & [9] \\
\hline \multirow[t]{2}{*}{ Machair } & Species composition of grassland & Maintained & {$[6]$} \\
\hline & Soil properties & Maintained & \\
\hline
\end{tabular}


lic, their willingness to pay for the environmental changes, having explained through a series of photographic montages and text descriptions the various outcomes of the scheme if the objectives are achieved.

Table IIIa shows the willingness to pay per resident household for four of the areas. For the Breadalbane and Machair areas a discrete choice approach was used to allow greater emphasis to be placed on the values of different components of the Scheme, whilst for Loch Lomond and the Stewartry areas an open-ended approach was adopted. No comparison was made between the methods. Irrespective of method, the estimates for annual willingness to pay per household for residents were similar for the four areas and of a similar amount to that for the general public of Scotland in the two areas for which this was studied, suggesting that use and non-use benefits may be similar. Visitors valued both the Breadalbane and Machair areas, particularly the latter area, more highly than residents or the general public mainly because of their high perception of its use value. Such a finding has been obtained in other studies [12].
Table III $b$ gives the aggregate willingness to pay figures for each of the areas. These are derived from the individual household figures, given in table IIIa, by multiplying them by the numbers of households in each category. The low populations in each of the areas are reflected in the low total aggregate figures. The low number of visitors to the Machair area, because of its distance from centres of population, explains its low aggregate value to visitors. What is important in terms of political perception is the last column which shows that for the two areas studied the aggregate benefit is very high. The United States government in a report [8] suggested that aggregate figures obtained by continent valuation methods should be reduced by an ad hoc factor of $50 \%$. Taking an extremely conservative view to allow for the fact that the respondents might misinterpret the specific benefits as being a more general environmental benefit (called part to whole bias), the aggregate benefit was also reduced by a factor of 10. Even allowing for these reductions in the aggregate benefit, the total willingness to pay by the general public of Scotland for the Breadalbane and Machair areas was $£ 7.0$

Table III. Willingness to pay estimates for the benefits arising from Environmentally Sensitive Areas in Scotland (from [4]).

\begin{tabular}{lccc}
\hline Area & Residents & Visitors & General public of Scotland \\
\hline $\begin{array}{l}\text { a) Household estimates }(\mathfrak{f}) \\
\text { Breadalbane }\end{array}$ & 31.4 & 98.0 & \\
Machair & 13.7 & 378.0 & 22.0 \\
Loch Lomond & 20.6 & N.D. & 13.4 \\
Stewartry & 13.0 & N.D. & N.D. \\
& & & N.D. \\
b) Aggregate estimates $(\mathfrak{f m})$ & 0.19 & 0.86 & \\
Breadalbane & 0.15 & 0.18 & 44.1 \\
Machair & 0.14 & $2.04^{\mathrm{a}}$ & 26.8 \\
Loch Lomond & 0.18 & $1.47^{\mathrm{a}}$ & N.D. \\
Stewartry & & & N.D. \\
\hline
\end{tabular}

N.D., not determined.

"Estimated on a per visit basis and then multiplied by estimates of the number of visits. 
million which is seven times the cost of implementing the Environmentally Sensitive Areas Scheme for the whole of Scotland (one million pounds) in 1996. This provides comfort to any government in its wish to increase expenditure on such a scheme in the future.

\section{ECONOMIC AND OTHER CONSEQUENCES TO THE RURAL SECTOR}

The consequence to farm income of farmers joining the Scheme in its early stages in the UK has been an increase in net farm income due to the payments being greater than the costs involved in complying with the simple prescriptions [2]. This was because the Schemes adopted initially combination of a payment of a flat rate for compliance with management guidelines and optional additional payments for specific management prescriptions [10]. This has been important in encouraging participation in the Scheme. As the Scheme has developed, there has been a move away from prescriptions solely to achieve environmental protection to those which involve environmental enhancement. It is likely that the net income benefits to farmers will decline as there are higher management costs often involved in these higher tier prescriptions. Because of the higher proportion of larger farms entering the Scheme, the net income benefits were found to be greater on such farms in one study [7].

The repair of walls and fencing has resulted in an increase in casual and contract labour which has helped to stimulate rural employment. This was found in the Breadalbane area [11] although such an effect may become diminished as the Scheme favours environmental enhancement. The increase in net farm income and additional rural employment will have benefited rural development through the multiplier effect. There may have been greater tourism and leisure marketing opportunities but these have not yet been quantified.

The Scheme has changed farm practices and enterprises with a shift to less extensive management systems, including reduction in stocking rates, and alterations in the balance of sheep and cattle enterprises [3]. It has also led to an increase in farmer's awareness of environmental issues and a change in their perceptions in their role as custodians of the countryside [1]

In conclusion, the Environmentally Sensitive Areas Scheme introduced in 1987 can be classed as having been successful. Although the actual environmental benefits achieved so far have been limited, more specific enhancement measures are likely to achieve this in the future. The general public of Scotland has been shown to value the scheme and it has been of benefit in increasing farm income.

\section{REFERENCES}

[1] Bullock C.H., McHenry H.L., A way forward for Environmentally Sensitive Areas that meets the needs of public and farmer, in: Sheldrick R.D. (ed.), Grassland Management in Environmentally Sensitive Areas, British Grassland Society Occasional Symposium No. 32, 1997. pp. 168-177.

[2] Colman D., Comparative evaluation of environmental policies, in: Whitby M.C. (ed.), Incentives for countryside management: the case for Environmentally Sensitive Areas, CAB International, Wallingford, 1994, pp. 219-252.

[3] Crabtree J.R., Barron N., Cost benefit to the taxpayer?, in: Sheldrick R.D. (ed.), Grassland Management in Environmentally Sensitive Areas, British Grassland Society Occasional Symposium No. 32, 1997, pp. 178-187.

[4] Hanley N., Simpson I., Parsisson D., MacMillan D., Bullock C., Crabtree J.R., Valuation of the conservation benefits of Environmentally Sensitive Areas, Economic and Policy Series 2, Macaulay Land Usc Research Institute, Aberdeen, 1996.

[5] Henderson D.J., Lilly A., Madden S., Still M.J., Heather Moorland Monitoring in the Loch Lomond Environmentally Sensitive Area, in: Thompson D.B.A., Hester A.J., Usher M.B. (eds.), Heaths and Moorlands: cultural landscapes, Her Majesty's Stationery Office, Edinburgh, 1996, pp. 334-339. 
(6) Henderson D.J., Hudson G., Towers W., The effects of ESA management guidelines on the Machair grasslands of the Uists and Benbecula, Outer Hebrides, in: Sheldrick R.D. (ed.), Grassland Management in Environmentally Sensitive Areas, British Grassland Society Occasional Symposium No. 32, 1997, pp. 234-236.

[7] Hughes G., ESAs in the context of a culturally sensitive area: the case of the Cambrian Mountains, in: Whitby M.C. (ed.), Incentives for countryside management: the case for Environmentally Sensitive Areas, CAB International, Wallingford, 1994, pp. 135-152.

18] National Oceanographic and Atmospheric Administration, Natural resource damage assessments: proposed rules, Federal Register 59 (1994) 1062-1191.

19| Nolan A.J., Henderson D.J., Still M.J., Madden S., Bell J.. The effects of excluding wild herbivores on the growth of established saplings in some woodlands within the Breadalbane and Loch
Lomond Environmentally Sensitive Areas In Scotland, Scottish Forestry, 1998, in press

[10] Scottish Office Agriculture, Environment and Fisheries Department, Merger of Scottish Agri-Environment Schemes: consultation document, Edinburgh, 1998.

[11] Skerrett S.J., Socio-economic evaluation of the Breadalbane Environmentally Sensitive Area Scheme, 1987-1990: results and critique, in: Whitby M.C. (ed.), Incentives for countryside management: the case for Environmentally Sensitive Areas, CAB International, Wallingford, 1994, pp. 105-134.

[12] Willis K.G., Garrod G.D., Saunders C.M., Valuation of the South Downs and Somerset Levels and Moors Environmentally Sensitive Area landscapes by the general public, A Report to the Ministry of Agriculture, Fisheries and Food, Centre for Rural Economy, Department of Agricultural Economics and Food Marketing, University of Newcastle upon Tyne, 1993. 